\title{
Influence of Sandblasted and Acid-etched Commercially Pure Grade II Titanium Surface on Human Osteosarcoma Osteoblast Cell Proliferation and Attachment: A Pilot Study
}

\author{
Raj Gaurav Singh
}

\begin{abstract}
Aim: To evaluate the effect of surface microtopography on osteogenic cell behavior.

Materials and methods: Commercially pure grade II titanium discs of similar design and dimensions ( $2.5 \mathrm{~mm} \times 6 \mathrm{~mm})$ were selected for the study. Samples were sandblasted using $110 \mu \mathrm{m}$ grit-size alumina $\left(\mathrm{Al}_{2} \mathrm{O}_{3}\right)$, and $15 \%$ hydrofluoric acid $(\mathrm{HF}), 96 \%$ sulphuric acid $\left(\mathrm{H}_{2} \mathrm{SO} \mathrm{O}_{4}\right)$, and $37 \%$ hydrochloric acid $(\mathrm{HCl}$ ) were used for acid etching. Scanning electron microscopy (SEM) with energy-dispersive X-ray spectroscopy (EDX) of samples was performed to observe the surface morphology and elemental analysis. Surface roughness was measured using a surface profilometer. Human osteosarcoma (HOS) cells were seeded at a density of $5 \times 10^{3}$ per test material and control cover slip and incubated for 48 hours. After critical point drying and gold sputtering, a scanning electron microscope was used to observe the cell morphology, proliferation, and cell attachment. Results: Scanning electron microscopy revealed that sandblasting and acid etching resulted in a homogeneous rough surface with a flatter profile. Energy-dispersive X-ray spectroscopy showed a significant increase in the oxygen content (29.38\%) after sandblasting and acid etching. Conclusion: Scanning electron microscopy result of the sandblasted and acid-etched surface showed that cell sheets were able to migrate into the pores and adhered inside the valleys suggesting excellent sign of osseointegration.

Keywords: Human osteoblast osteosarcoma cells, Sandblasted and acid-etched, Titanium.

International Journal of Prosthodontics and Restorative Dentistry (2019): 10.5005/jp-journals-10019-1252
\end{abstract}

\section{INTRODUCTION}

The clinical practice of implants in the dentistry and orthopedics continues to expand. ${ }^{1}$ Replacing missing teeth with osseointegrated implants can be regarded as the most significant breakthrough in the dental profession. ${ }^{2}$ Titanium is the implant material of choice for use in dental and orthopedic applications because of its osseointegration ability. ${ }^{2,3}$ The stable oxide that forms readily on titanium surfaces was reported to contribute to its excellent biocompatibility. ${ }^{4}$ The nature of the oxide (thickness, porosity, and crystallinity) also affects in vivo performance. ${ }^{5}$ However, it was also found that the bone response to the implant surface was dependent on the chemical and physical properties of titanium surfaces, thereby affecting implant success. ${ }^{6}$ In search for altering the surface characteristics to enhance the implant survival rate, much attention has been focused on changes in surface roughness and chemistry. ${ }^{7}$ Macroscopic mechanical interlocking can provide initial stability of the implant, allowing time for surface reactions that lead to osseointegration. ${ }^{8}$ Therefore, the present study is an approach to optimize a standard surface morphology and assessment of cell behavior toward it.

\section{Materials and Methods}

\section{Sample Preparation}

Samples were cut from the grade II commercially pure titanium rod to form discs ( $2.5 \mathrm{~mm}$ width $\times 6 \mathrm{~mm}$ diameter) at Central Training Institute, Chennai, Tamil Nadu, India. Ten $(n=10)$ samples were selected for the study. A 1-mm-diameter screw hole is prepared at the width of the sample to attach the metal rod with the soldered screw on its tip. A dental lathe (Apex industrial electronics, India) was used at 2,800 rpm for polishing of samples. A wooden fixture
Department of Oral Rehabilitation, Faculty of Dentistry, University of Otago, Dunedin, Otago, New Zealand

Corresponding Author: Raj Gaurav Singh, Department of Oral Rehabilitation, Faculty of Dentistry, University of Otago, Dunedin, Otago, New Zealand, Phone: +64 0210497050, e-mail: gauravdentist@ gmail.com

How to cite this article: Singh RG. Influence of Sandblasted and Acid-etched Commercially Pure Grade II Titanium Surface on Human Osteosarcoma Osteoblast Cell Proliferation and Attachment: A Pilot Study. Int J Prosthodont Restor Dent 2019;9(4):108-112.

Source of support: Nil

Conflict of interest: None

mount was prepared and samples with rod were stabilized at $45^{\circ}$ on it, maintaining a distance of $0.5 \mathrm{~cm}$ from the mandrel. All samples were abraded with 500,800, and 1,200 grit silica carbide paper (Malani abrasives, New Delhi, India) for 1 minute to achieve a similar surface. Samples underwent an ultrasonic cleaning procedure for 180 seconds in acetone using an ultrasonic cleaner (AC-B8, Guangzhou Fengdan Medical Equipment Co. Ltd, China). The procedure was repeated once again after changing acetone. The samples were placed in a burn-out furnace at $100^{\circ} \mathrm{C}$ for 1 minute to remove surface moisture.

\section{Surface Characterization}

Samples were handled carefully after wearing latex gloves. The samples were held with tweezers taking care not to damage or contaminate the flat surface. Samples were attached to the fixture mount and sandblasting (MS Surgical, Chennai, Tamil Nadu, India) was done with a sandblaster equipment. Sandblasting of all samples was done using $110 \mu \mathrm{m}$ grit size alumina $\left(\mathrm{Al}_{2} \mathrm{O}_{3}\right)$ for 1 minute at a 
pressure of $5 \mathrm{~kg} / \mathrm{cm}^{2}$. The distance between the nozzle and the sample was standardized at $2 \mathrm{~cm}$. Samples again underwent an ultrasonic cleaning procedure in acetone for 180 seconds (twice) in order to remove any residual alumina on the surface. Each sample was dipped at room temperature in three different acids- $15 \%$ hydrofluoric acid (HF), $96 \%$ sulphuric acid $\left(\mathrm{H}_{2} \mathrm{SO}_{4}\right)$, and $37 \%$ hydrochloric acid $(\mathrm{HCl})$. Each sample was attached to a screw soldered with a metal rod for commencement of acid etching. Around $40 \mathrm{~mL}$ of each acid was transferred in a glass tumbler. The $20 \%$ sodium bicarbonate $\left(\mathrm{Na}_{2} \mathrm{CO}_{3}\right)$ solution and deionized water were kept separately. $\mathrm{Na}_{2} \mathrm{CO}_{3}$ served as a neutralizing agent to prevent excessive etching of the titanium disks. Following steps were performed for acid treatment of all samples:

- Dip in $15 \%$ HF for 1 minute.

- Shake well in deionized water for 10 seconds.

- Dip in $20 \% \mathrm{Na}_{2} \mathrm{CO}_{3}$ for 30 seconds.

- Dip in $96 \% \mathrm{H}_{2} \mathrm{SO}_{4}$ for 4 minutes.

- Shake well in deionized water for 10 seconds.

- Dip in $20 \% \mathrm{Na}_{2} \mathrm{CO}_{3}$ for 30 seconds.

- Dip in $37 \% \mathrm{HCl}$ for 4 minutes.

- Shake well in deionized water for 10 seconds.

- Dip in $20 \% \mathrm{Na}_{2} \mathrm{CO}_{3}$ for 30 seconds.

Ultrasonic cleaning of samples was done using acetone to remove any residue of chemicals for 180 seconds for two times and samples were air-dried.

\section{Surface Analysis}

Scanning electron microscopy (SEM) and energy-dispersive X-ray spectroscopy (EDX) were done to evaluate surface morphology and elemental analysis (Model S-3400, Hitachi, Japan). The surface roughness of samples was evaluated with a surface profilometer (Horizon Noncontact Optical Profilometer, Burleigh Instruments).

\section{Sterilization of Samples}

All samples were kept in a burn-out furnace at $400^{\circ} \mathrm{C}$ for 2 minutes to kill all bacteria spores. The samples were transferred to glass vials that had been ultrasonically cleaned previously. Each vial had a minute perforation in the cap to allow steam entry during autoclaving. The vials with samples were finally autoclaved at $121^{\circ} \mathrm{C}$ for 20 minutes.

\section{Cell Culture Study}

Human osteosarcoma osteoblast cell lines (NCCS, Pune, Maharashtra, India) were used as per the previous studies by Anil Kumar et al. ${ }^{9,10}$ Cells were cultured and maintained in the Iscove's modified Dulbecco medium (IMDM) supplemented with $5 \%$ fetal bovine serum (FBS) and $100 \mathrm{IU} \mathrm{mL} \mathrm{mL}^{-1}$ penicillin and $100 \mu \mathrm{g} \mathrm{mL}^{-1}$ streptomycin in a $\mathrm{CO}_{2}$ incubator (Nuaire, USA) at $37^{\circ} \mathrm{C}$ with $95 \%$ humidified atmosphere containing $5 \% \mathrm{CO}_{2}$. Human osteosarcoma (HOS) cells were seeded at a density of $5 \times 10^{3}$ per test material and control cover slip (Fig. 1). Cells were incubated with test samples for 48 hours at $37 \pm 2^{\circ} \mathrm{C}$. Samples were observed under an optical microscope after 24 hours for cell morphology and attachment on the control cover slip (Fig. 2). The medium was removed and cells were fixed in 3\% glutaraldehyde for minimum 1 hour. Samples were rinsed with $0.1 \mathrm{M}$ phosphate buffer solution ( $\mathrm{pH}$ 7.2) for 3 minutes twice. Samples will be then be dehydrated in successive solutions of $30,50,70,90,95$, and $100 \%$ alcohol (ethanol). Processing was done for critical point drying. Gold coating (E-1010 ion sputter, Hitachi, Japan) was done and samples were observed under a scanning electron microscope (Model S-3400, Hitachi, Japan) at magnification of $500 \times$ and $1000 \times$ at an acceleration voltage of $20 \mathrm{kV}$.

\section{Results}

\section{Surface Analysis Results}

Samples were subjected to SEM at magnification of $500 \times$ and $1000 \times$ at an acceleration voltage of $15 \mathrm{kV}$. Scanning electron microscopy images showed a distinct microporous surface. A very rough, highly irregular surface with numerous depressions and indentations was present (Figs 3 and 4). The elemental analysis using EDX shows percentage values of elements present on the surface and also shows an increased oxygen content (Table 1). Peak values of elements present are shown in Figure 5. Energydispersive X-ray spectroscopy also shows a high peak value for $\mathrm{Ti}$ and a significant increase in the peak value of oxygen. Surface profilometry shows microscale roughness values of the sandblasted and acid-etched samples (Table 2). Flat surfaces of the test samples were examined.

\section{Cell Proliferation Results}

Samples were subjected to SEM at magnification of 500x and $1000 \times$ at an acceleration voltage of $20 \mathrm{kV}$. The proliferation result shows homogeneous spread of cell patches (Fig. 6) and cells were able to proliferate and attach to the microirregularities (Fig. 7). Cells were viable and there was no sign of cytotoxicity, which suggested excellent biocompatibility of the surface.

\section{Discussion}

The titanium surface readily oxidizes to form several stable oxides such as $\mathrm{TiO}_{2}, \mathrm{TiO}$, and $\mathrm{Ti}_{2} \mathrm{O}_{3}$ with the former being the most common. This property makes titanium highly corrosion-resistant. The oxide thickness increases from $10 \AA$ within a millisecond to 50-100 within a minute. Surface roughness improves the mechanical strength at the interface and can also influence chemical bonding by altering the van der Waals forces. ${ }^{1,4}$

The concept of osseointegration was defined and the clinical and experimental approaches demonstrating osseointegration were summarized by Thomas Alberktsson. ${ }^{11}$ He reviewed important implant parameters determining the bone-metal interface reactions around an inserted titanium screw. The author considered the surface structure as an important factor for osseointegration.

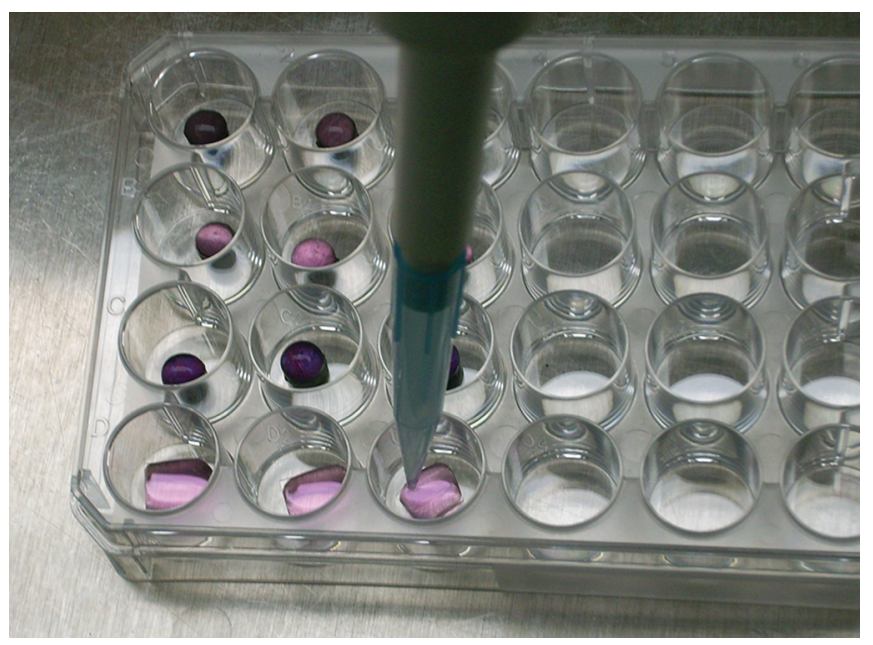

Fig. 1: Cell seeding on samples and the control cover slip 


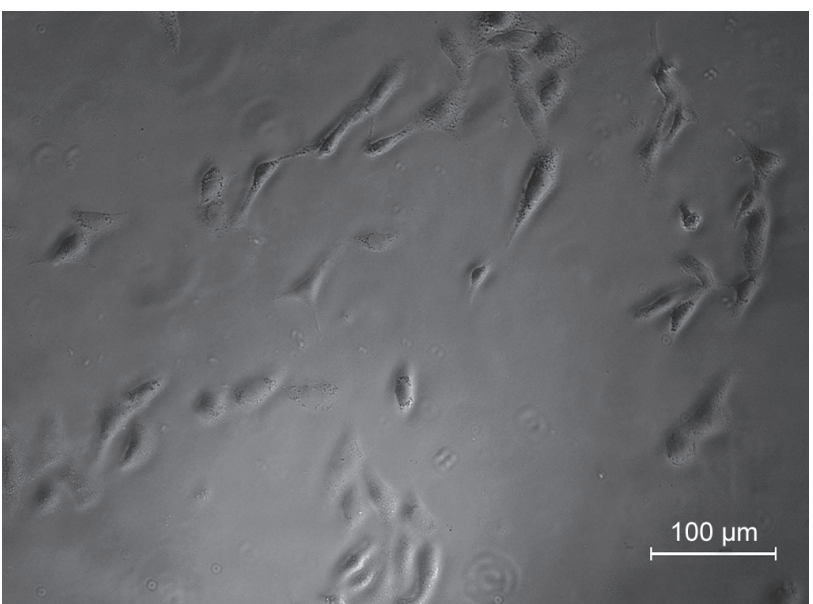

Fig. 2: Human osteosarcoma on the cover slip after 24 hours

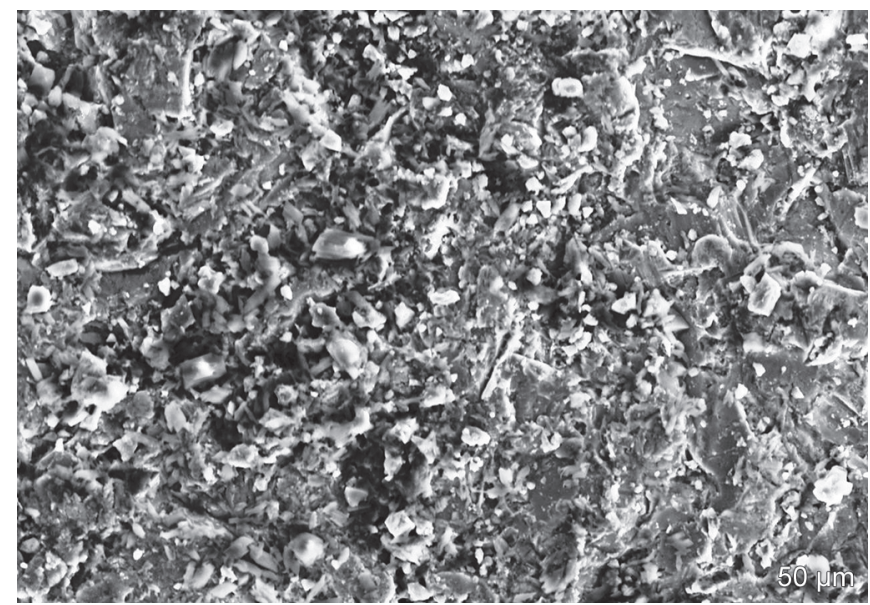

Fig. 4: Scanning electron microscopy at $1000 \times$ showing surface roughness

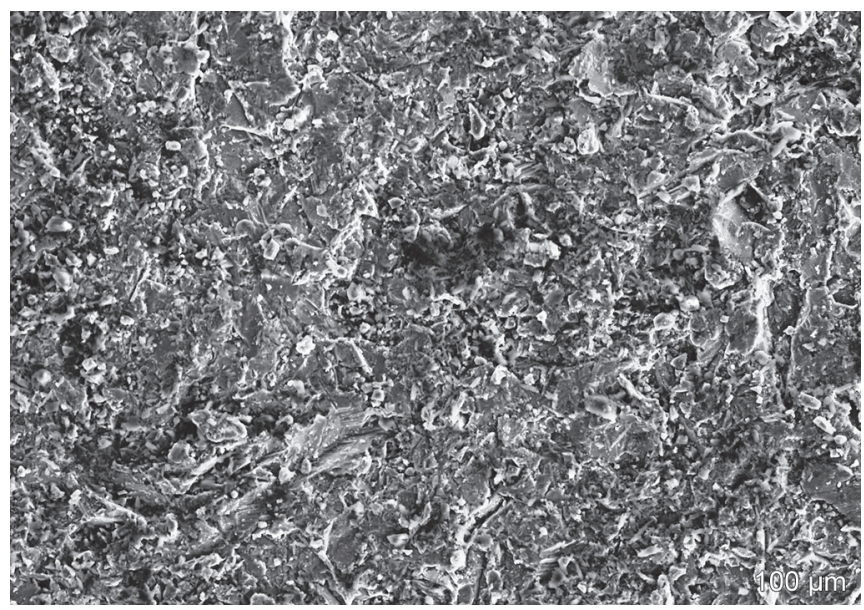

Fig. 3: Scanning electron microscopy at $500 \times$ showing surface roughness

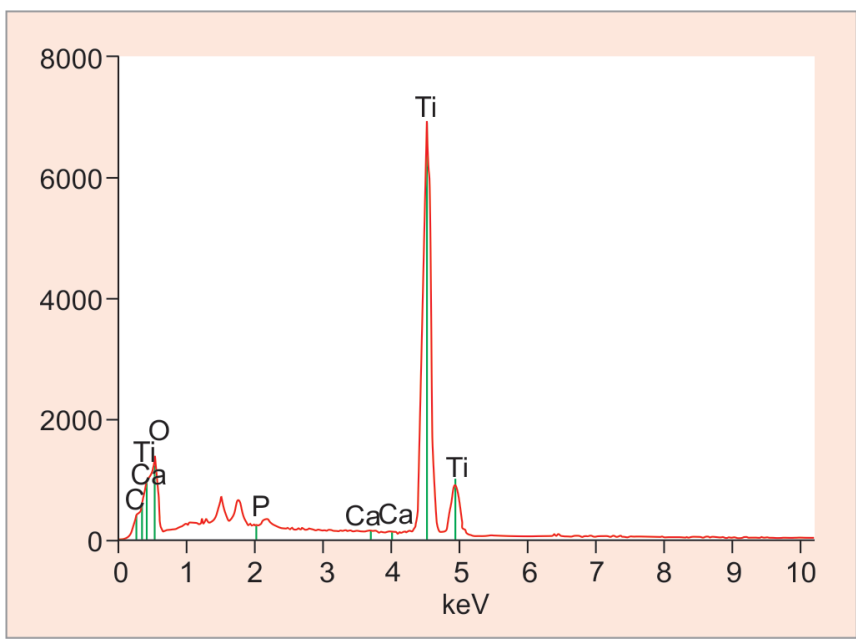

Fig. 5: Peak values of elements on the sample. Live time: 100.0 seconds; accelerating voltage: $15.0 \mathrm{kV}$; take-off angle: $35.0^{\circ}$; full scale count $=6,931$; base $=1,640$

Table 1: Quantitative results of elemental analysis for base $(1,640)$

\begin{tabular}{lllcrrr}
\hline Element & Net counts & Net counts error & Weight (\%) & Atom (\%) & Formula & Compnd (\%) \\
\hline $\mathrm{C}$ & 4,942 & \pm 340 & 12.79 & 25.92 & $\mathrm{C}$ & 12.79 \\
$\mathrm{O}$ & 13,079 & \pm 1194 & 29.38 & 44.69 & $\mathrm{O}$ & 29.38 \\
$\mathrm{P}$ & 0 & \pm 120 & 0.00 & 0.00 & $\mathrm{P}$ & 0.00 \\
$\mathrm{Ca}$ & 214 & \pm 156 & 0.07 & 0.04 & $\mathrm{Ca}$ & 0.07 \\
$\mathrm{Ca}$ & 0 & \pm 252 & - & - & & - \\
$\mathrm{Ti}$ & 107,464 & \pm 990 & 57.76 & 29.35 & $\mathrm{Ti}$ & 57.76 \\
$\mathrm{Ti}$ & 8,169 & \pm 1400 & - & - & & - \\
Total & & & 100.00 & 100.00 & & 100.00 \\
\hline
\end{tabular}

Wennerberg et al. ${ }^{12}$ compared the bone response in rabbit tibiae to machined, $25 \mu \mathrm{m}$ alumina-blasted and $250 \mu \mathrm{m}$ alumina-blasted implants. A blast pressure of $0.36 \mathrm{MPa}$ and speed of $20 \mathrm{rpm}$ were used for sandblasting. After 1 year, the bone-implant contact (BIC) percentage and removal torque were significantly higher in the sandblasted implants with no significant difference between both. Ionic levels of $\mathrm{Ti}$ ions were similar at $2 \mathrm{~mm}$ for both machined and blasted implants.

The greater bone response to the sandblasted surface was attributed to its surface characteristics. Wennerberg et al. ${ }^{13}$ observed the bone response to machined and sandblasted implant surfaces in rabbits. Each implant was prepared with two different surface roughnesses along its longitudinal aspect resulting in the following groups: group I: $25 \mu \mathrm{m} \mathrm{Al}_{2} \mathrm{O}_{3}$ vs machined, group II: 250 $\mu \mathrm{m} \mathrm{Al}_{2} \mathrm{O}_{3}$ vs machined, group III: $25 \mu \mathrm{m} \mathrm{Al} \mathrm{O}_{3}$ vs $75 \mu \mathrm{m} \mathrm{Al}_{2} \mathrm{O}_{3}$, and group IV: $25 \mu \mathrm{m} \mathrm{Al} \mathrm{O}_{3}$ vs $250 \mu \mathrm{m} \mathrm{Al} \mathrm{O}_{3}$. The $75 \mu \mathrm{m}$ blasted surfaces appeared superior and an optimal roughness value of $\mathrm{Sa}, 1.4 \mu \mathrm{m}$, was suggested for a better bone response.

In a study by Buser et al., ${ }^{14}$ removal torque testing was performed after 4,8 , and 12 weeks of healing in the maxillae of 
Table 2: Surface profilometer results

\begin{tabular}{llll}
\hline Sample & $R_{a}$ & $R_{z}$ & $R_{\max }$ \\
\hline Sandblasted and acid-etched & 1.55 & 5.57 & 14.3 \\
\hline
\end{tabular}

$R_{\mathrm{a}}=$ roughness average, $R_{\mathrm{z}}=10$-point mean roughness, and $R_{\max }=$ maximum profile valley depth

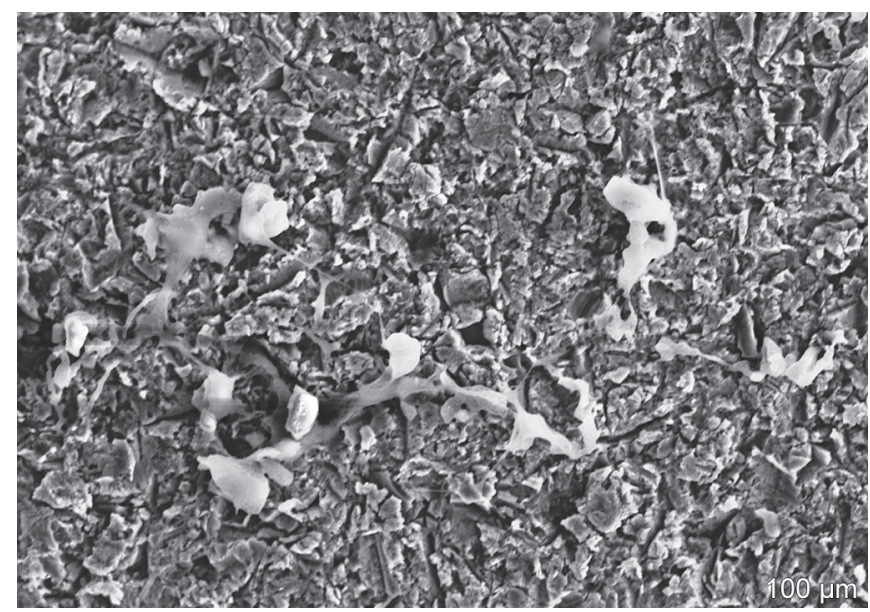

Fig. 6: Scanning electron microscopy at 500 $\times$ showing cell attachment

mini pigs. The author compared sandblasted/large-grit/acidetched (SLA) and dual acid-etched (DE) implants biomechanically. The mean removal torque value (RTV) for the SLA surface was significantly higher than the DE surface at all time intervals.

Piatelli et al. ${ }^{15}$ compared the difference in the bone response to machined (Ra $0.80 \mu \mathrm{m}$ ) and sandblasted (Ra $2.09 \mu \mathrm{m}$ ) implant surfaces placed in the rabbit tibia over a period of 8 weeks. Sandblasting was achieved using $150 \mu \mathrm{m} \mathrm{Al}_{2} \mathrm{O}_{3}$ with a blast pressure of 20 psi and blast time of 15 seconds. The histomorphometric analysis showed that sandblasted implants presented a significantly higher BIC percentage from the 3rd week onward. Marinho et al. ${ }^{16}$ observed that the bone response in rabbits to SLA implants was significantly greater than to machined implants after 30 days and 60 days. The Ra values of SLA and machined implants were $2.15 \mu \mathrm{m}$ and $0.86 \mu \mathrm{m}$, respectively.

Biomechanically, rougher etched implants are superior to smoother machined implants. Baker et al. ${ }^{17}$ compared the rate of gain of pull-out strength of machined and dual-etched $(\mathrm{HCl} /$ $\mathrm{H}_{2} \mathrm{SO}_{4}$ ) titanium implants placed in five rabbit tibiae over 8 weeks. The etched implants had higher shear strength at the 3rd week with further significant increase till the 8th week. Shear strength of machined implants remained low throughout the observation period. Cordiolli et al. ${ }^{18}$ compared the bone response to four different implant surfaces in 12 rabbits: machined, titanium dioxide $\left(\mathrm{TiO}_{2}\right)$-blasted, titanium plasma-sprayed (TPS), and acid-etched (warm $\mathrm{HF}+\mathrm{HCl} / \mathrm{H}_{2} \mathrm{SO}_{4}$ ). After 5 weeks, histomorphometric and removal torque data revealed a greater bone response to the acidetched implants.

Berglundh et al. ${ }^{19}$ investigated wound healing around SLA implants placed in dog mandibles by histologic methods. It was postulated that the SLA surface was osteoconductive since previously de novo bone formation had not been seen with smoother machined implants in the same animal model. Surface chemistry is an important variable that must be taken into consideration when comparing different topographies. Acid etching has the advantage of removing contaminants and maintaining better titanium percentages.

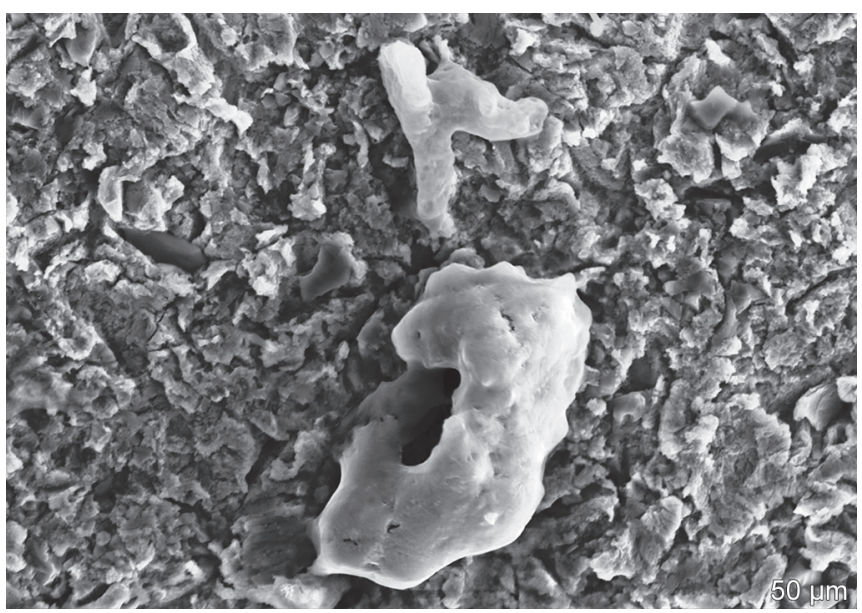

Fig. 7: Scanning electron microscopy at $1000 \times$ showing cell attachment

Shirakura et al. ${ }^{20}$ evaluated the tissue response to SLA- and HA (hydroxyapatite)-coated implants placed in rat maxillae. Sandblasted/ large-grit/acid-etched surfaces exhibited distance osteogenesis while HA-coated implants exhibited contact osteogenesis. Both groups demonstrated osseointegration at the end of 28 days. The SLA surface was concluded to be nonosteoconductive and the HA surface osteoconductive.

Bioactivity of titanium was assessed using several cell lines in the past. MG-63 human osteoblasts and L929 mouse fibroblasts are the most common cell line used for this purpose. Human osteosarcoma osteoblast, a mammalian cell line, is a wellestablished and characterized cell line with documented in vitro results. Surface morphology and composition influence cells to form a tissue layer and formation of the mineralized bone matrix..$^{9,10}$ Singh ${ }^{21}$ evaluated response of HOS osteoblast cell lines on polished, SLA, and sol-gel dip-coated titanium surfaces and found similar results as the present study.

\section{Conclusion}

The sandblasted and acid-etched rough surface showed cell sheets were able to penetrate into the pores and adhered inside the valleys suggesting excellent proliferation and attachment. However, further studies are needed to assess gene expressions of osteoblast cells and bone matrix formation around this surface.

\section{ACKNOWLedgments}

Author wish to thank Dr D. Sendhilnathan and DrE. Munirathahnam Naidu for their guidance and support for the study. The author also would like to acknowledge Dr Anil Kumar, Implant Biology Section from Sree Chitra Tirunal Institute for Medical Sciences and Technology, Thiruvananthapuram, Kerala, India for the cell culture study.

\section{References}

1. Puleo DA, Thomas MV. Implant surfaces. Dent Clin N Am 2006;50: 323-338. DOI: 10.1016/j.cden.2006.03.001.

2. Branemark PI, Hansson BO, Adell R, et al. Osseointegrated implants in the treatment of the edentulous jaw. Experience from a 10-year period. Scand J Plast Reconstr Surg 1977;16(Suppl 1):7-127.

3. Alberktsson T, Branemark PI, Hansson HA, et al. Osseointegrated titanium implants. Requirements for ensuring a long-lasting, direct bone-to-implant anchorage in man. Acta Orthop Scand 1981;52(2):155-170. DOI: 10.3109/17453678108991776. 
4. Kasemo B. Biocompatibility of titanium implants: surface science aspects. J Prosthet Dent 1983;49(6):832-837. DOI: 10.1016/00223913(83)90359-1.

5. Choi JW, Heo SJ, Koak JY, et al. Biological responses of anodized titanium implants under different current voltages. J Oral Rehabil 2006;33(12):889-897. DOI: 10.1111/j.1365-2842.2006.01669.x.

6. Buser D, Schenk RK, Steinmann S, et al. Influence of surface characteristics on bone integration of titanium implants. A histomorphometric study in miniature pigs. J Biomed Mater Res 1991;25(7):889-902. DOI: 10.1002/jbm.820250708.

7. Shalabi MM, Gortemaker A, Van't Hof MA, et al. Implant Surface Roughness and Bone Healing: a Systematic Review. J Dent Res 2006;85(6):496-500. DOI: 10.1177/154405910608500603.

8. Brunette DM. The effects of implant surface topography on the behavior of cells. Int J Oral Maxillofac Implants 1998;3(4):231-246.

9. Anil Kumar PR, Varma HK, Kumary TV. Rapid and complete cellularization of hydroxyapatite for bone tissue engineering. Acta Biomater 2005;1(5):545-552. DOI: 10.1016/j.actbio.2005.05.002.

10. Anil Kumar PR, Varma HK, Kumary TV. Cell patch seeding and functional analysis cellularized scaffolds for tissue engineering. Biomed Mater 2007;2(1):48-54. DOI: 10.1088/1748-6041/2/1/008.

11. Alberktsson T. Bone-metal interface in osseointegration. J Prosthet Dent 1987;57(5):597-607. DOI: 10.1016/0022-3913(87)90344-1.

12. Wennerberg A, Ektessabi A, Albrektsson T, et al. A 10 year follow-up of differing surface roughness placed in rabbit bone. Int J Oral Maxillofac Implants 1997;12:486-494.

13. Wennerberg A, Hallgren C, Johansson C, et al. A histomorphometric evaluation of screw-shaped implants each prepared with two surface roughnesses. Clin Oral Imp Res 1998;9(1):11-19.
14. Buser D, Nydegger T, Hirt HP, et al. Removal torque values of titanium implants in the maxilla of miniature pigs. Int J Oral Maxillofac Implants 1998;13(5):611-619.

15. Piatelli A, Manzon L, Scarano A, etal. Histologic and histomorphometric analysis of the bone response to machined and sandblasted titanium implants: an experimental study in rabbits. Int J Oral Maxillofac Implants 1998;13(6):805-810.

16. Marinho V, Celletti R, Brachetti G, et al. Sand-blasted and acid-etched dental implants: a histological study in rats. Int J Oral Maxillofac Implants 2003;18(1):75-81.

17. Baker D, London RM, O'Neal R. Rate of pull-out strength gain of dualetched titanium implants: a comparative study in rabbits. Int J Oral Maxillofac Implants 1999;14(5):722-728.

18. Cordiolli G, Majzoub Z, PiateUi A, et al. Removal torque and histomorphometric investigation of 4 different titanium surfaces: an experimental study in rabbit tibia. Int J Oral Maxillofac Implants 2000;15(5):668-674.

19. Berglundh T, Abrahamsson I, Lang NP, et al. De-novo alveolar bone formation adjacent to endosseous implants. Clin Oral Impl Res 2003;14(3):251-262. DOI: 10.1034/j.1600-0501.2003. 00972.x.

20. Shirakura $M$, Fujii $N$, Ohnishi $H$, et al. Tissue response to titanium implantation in the rat maxilla, with special reference to the effects of surface conditions on bone formation. Clin Oral Impl Res 2003;14(6):687-696. DOI: 10.1046/j.0905-7161.2003. 00960.x.

21. Singh RG. Evaluation of bioactivity of titanium after varied surface treatments using human osteosarcoma osteoblast cells-An in vitro study. Int J Oral and Maxillofac Implants 2011;26(5):998-1003. 